\title{
Relations of Ruling in the Colonial Present: An Intersectional View of THE ISRAELI IMAGINARY
}

\author{
Madalena SAntos
}

Abstract. This article presents a categorical framework for the interrogation of power relations in the study and analysis of Israeli colonialism in Palestine. Following critical antiracist feminist approaches, I highlight the relationship between race, class, and gender constructions that are crucial to colonial rule. Extending Chandra Mohanty's (1991) reading of Dorothy Smith's "relations of ruling," I outline six intersecting categories of colonial practices to examine Israel's particular colonization forms and processes. These categories include: racial separation; citizenship and naturalization forms and processes; construction and consolidation of existing social inequalities; gender, sexuality, and sexual violence; racialized and gendered prisoners; and "unmarked" versus "marked" discourses. Understanding colonial experiences as heterogeneous and plural, I conclude by arguing for the furthering of decolonial and antiracist feminist analyses from within specific sites of resistance.

Keywords: Israel/Palestine; settler colonialism; ethno-nationalism; racialization; gender; citizenship.

Résumé. Cet article présente un cadre d'analyse pour l'interrogation des relations de pouvoir au sein de l'étude et l'analyse de la colonisation israélienne de la Palestine. En suivant les approches critiques antiracistes féministes, je souligne le relationnisme entre la construction de la race, la classe et le genre qui sont cruciaux à la domination coloniale. Poursuivant l'interprétation des « relations of ruling » de Dorothy Smith par Chandra Mohanty (1991), j'esquisse six catégories des pratiques coloniales sécantes pour examiner les formes et processus particuliers de colonisation par Israël. Ces catégories incluent: la séparation raciale; les formes et les processus de citoyenneté et naturalisation, la construction et la consolidation des inégalités sociales existantes, le genre, la sexualité et la violence sexuelle, les prisonniers basés sur le genre et la race, et les discours «non marqués» par opposition aux discours «marqués». En comprenant que les expériences coloniales sont hétérogènes et multiples, je conclus en faisant valoir et en plaidant pour la poursuite des analyses de décolonisation et des analyses antiracistes féministes au sein des espaces spécifiques de résistance.

Mots clés: Israël/Palestine; colonialisme de peuplement; ethno-nationalisme; racialisation; le genre; la citoyenneté. 


\section{INTRODUCTION}

hrough the interweaving of Zionist myths of nation, identity, and security, Israel presents itself as the national homeland for all Jewish peoples - a land under constant threat of annihilation by Palestinians who are discursively constructed as demographic and security risks. Yet, the Zionist project of Eretz Israel (our land of Israel) is one of colonization which bases the survival and vitality of the state's Jewish population on the removal and absence of the racialized Palestinian other. Israel has continued its settler colonial project in Palestine, with its distinct forms of occupation (Zureik 2011:4) and apartheid (Davis 1987), through state discourses and practices of separation, fragmentation, and violence. Adding to recent work concerning Israel's discursive, systemic, and performative racialization of Palestinians (e.g., Abu-Laban and Bakan 2008, 2011; Abu El-Haj 2010; Lentin 2004, 2008; Goldberg 2008), this article offers a categorical framework that underlines the relationality between race, class, and gender that has been central to the structuring network of Zionist colonization from its initial stages to the colonial present. ${ }^{1}$

Like Patrick Wolfe (2006) who underscores the identifiable features of the structure of settler colonialism, most definitively in what he terms "the logic of elimination," I understand settler colonialism as an ongoing project rather than an event. According to Wolfe (2006:105), the logic of elimination ${ }^{2}$ is a historically continuous "structural feature," endemic to all settler colonial projects, that includes the elimination of indigenous people through the erasure of language, culture, traditions, and communities as well as through mass killing. This type of project is never about situational discriminations or circumstantially racialized practices; instead, as Wolfe argues (2006:103), settler colonialism is based on the expropriation of land from indigenous populations for the erection of a "new colonial society." Settler colonial projects thus require the utilization of discriminatory and racialized processes to enable the establishment of the state and the continuation of state pursuits.

1. Following Derek Gregory (2004:xiv-xx), I use the term colonial present to complicate Israel's historical narrative that attempts to homogenize time to show that histories are "always plural, always contested, and shot through with multiple temporalities ane "always plura,

2. Wolfe (2006) argues that "the logic of elimination" more accurately captures the intents and practices of settler colonialists who seek to kill indigenous peoples in symbolic, material, and physical respects than the term genocide. I utilize the terms ethnic cleansing and genocide which carry legal weight to discuss how the Zionist state came into being and still tries to eliminate Palestinians, not only through the purposeful destruction of their history in the renaming of place and space and forcible removal of the population, but also in the physical sense of the planned murder of people such as in the $2008-2009$ as well as 2012 Gaza bombings.
To examine the Zionist project of settler colonialism in Palestine, I invoke Chandra Mohanty's (1991) reading of Dorothy Smith's "relations of ruling" which enables the exploration of power relations in particular contexts. Mohanty's third world feminist approach to relations of ruling bridges historical materialism with poststructuralist thought to consider multiple intersections of structures of power. Her method reveals a number of "othering" forms and processes that are operative in relations of ruling to create differences between peoples that legitimate the authority of ruling in the colonial and imperial context of rulers and "natives," and in the liberal capitalist states of citizens and noncitizens. Importantly, her approach avoids simplistic positioning which can reduce relations of power to binary oppositions of oppressor versus oppressed and the normalizing (or naturalizing) of individuals or structures; instead, she stresses the identification and location of transformations in power to emphasize "the process of ruling" rather than "the frozen embodiment of it" in: "(1) forms of knowledge and (2) organized practices and institutions, as well as (3) questions of consciousness, experience, and agency"(Mohanty 1991:14). While Mohanty (1991:17-23) does not describe the forms and processes of colonial and liberal-capitalist rule as categories of analysis, I identify the mechanisms and techniques of rule jointly and identify them as falling into six broad and interconnected categories:

- Racial separation

- Citizenship and naturalization forms and processes

- Construction and consolidation of existing social inequalities

- Gender, sexuality, and sexual violence

- Racialized and gendered prisoners

- "Unmarked" versus "marked" discourses

I utilize these groupings for two interrelated purposes: One, I seek to interrogate historical simplifications of Israel as victim which silence and erase Palestinian narratives of the 1948 establishment of the state of Israel or "al Nakba" (Arabic for "the Catastrophe"); and two, I endeavour to question Israel's dual claim of Jewish exclusivity and liberal democratic inclusivity even as it continues practices of ethnic cleansing, dispossession, displacement, exile, and genocide against Palestinians. Contributing to the recent but emergent literature which examines Israel as a settler colonial state (see Zureik 2011:5), my article further provides a new lens on existent studies on Israel/Palestine by introducing a nexus of theoretical tools for the sociological study of settler colonial projects.

In situating Israel's ongoing settler colonial project within a framework of relations of ruling, I also add to new areas of research that aspire 
to change how Palestinian political struggles are conceived and discussed by Western academia (see Abdo 2011; Masalha 2012:149; Nadeau and Sears 2010; Puar 2011; Sheehi 2010:267). Paying particular attention to the intersection of "socioeconomic, political, and discursive configurations" (Mohanty 1991:14) of colonialism, the state, citizenship, race, gender, and class, I engage critical feminist (Abdo 1996, 2008, 2011; Bannerji 2003; Kanaaneh 2002, 2009; Ong 1996) and postcolonial literature (Mbembé 2003; Said 1978) through a Foucauldian lens which facilitates an examination of power relations in colonial contexts. After examining Zionist discourses and practices of colonization in Palestine, I conclude by arguing for further decolonial and antiracist feminist analyses to adequately comprehend, theorize, as well as overcome the violent nature of Israel's contemporary settler colonial project.

\section{Racial Separation}

From the first imaginings of the Israeli nation-state as a homeland for all Jewish peoples, Zionism has been preoccupied with the question of ethno-demography and a desire to separate Jews in Palestine from the indigenous Arab population (Kanaaneh 2002:28; Pappe 2007:13, 34-5). Since Zionism set Israel out to be the Jewish nation for Jews regardless of where they resided and/or claimed citizenship at the time, there was a perceived need to make Jews the majority of the population (Davis 1987:9). As is well documented in much of the literature on Zionism, Jews made up one-third of the population and owned less than 7 percent of all the land of Palestine prior to al Nakba (Davis 1987:22; Falah 1996; Khalidi 2001:12; Pappe 2007:29-30; Yuval-Davis 1987:39). To secure a land base for the Jewish population, the Zionist colonial project that established the state of Israel in May 1948, and which continues in the colonial present, involved the forced expulsion, exile, imprisonment, murder, massacre, and political assassination of Palestinians as well as the destruction of over 500 Palestinian towns and villages (Davis 1987; Falah 1996; Masalha 2012; Pappe 2007). Although implemented and performed by Zionist rule, these practices were facilitated through the laws and governance of Western colonialist forces.

As a direct result of British rule, in particular the Balfour Declaration, concrete steps were taken to ensure the creation of the Zionist state (AbuLaban and Bakan 2008:647; Pappe 2007:13). In the aftermath of the Holocaust in Europe the United Nations Special Committee for Palestine (UNSCOP) appealed to the international community to take responsibility for the Jewish refugee problem; however, this call went unanswered (Khalidi 1997:9). Instead, the United Nations General Assembly through the United Nations Partition Plan Resolution 181 solidified Balfour's promise on November 29, 1947 with its demarcation of Palestine into two separate states without the consent of Palestinians and with no regard for the ethnic make-up of Palestine. This enabled the Zionist leadership to implement Plan Dalet — a plan of systematic and total expulsion of the Palestinian people from Palestine (Pappe 2007:28).

Importantly, what motivated the British Empire's assistance in bringing the Zionist plan to ethnically cleanse Palestine to fruition was its own desire to relocate the Jewish people - at the time considered to be nonwhite - outside of Europe (Abu-Laban and Bakan 2008:647). The white Christian peoples of Europe had long discriminated against and held racialized beliefs about Jewish peoples; yet, as Hannah Arendt (1973:158-61) makes clear, the escalation of racism against Jewish peoples intensified as a result of late 19th century European colonial and imperial expansion in which race-thinking played a crucial and prominent role in defining people as racially inferior and backward. While studies on the ethnic cleansing of Palestine began to gain circulation in the 1980s through the work of Israel's "new historians" (e.g., Avi Shlaim, Benny Morris, Ilan Pappe - see Masalha 2012:148-204), examining the Zionist goal of the Israeli state through the rubric of racism and racialization is fairly recent (see Goldberg 2008; Lentin 2004).

The seemingly evident contradiction between political Zionism and what is construed as modern secular racism are complexly interrelated. Notably, the increase in anti-Jewish sentiment during the Nazi period resulted in increased support for the Zionist movement which had not received a great deal of backing from Jewish peoples previously (AbuLaban and Bakan 2008:645-646; Davis 1987:2-3). The historical foundation for Zionist ideology that began as a political response to racism "through the construction of an ethnically-defined and exclusively 'Jewish' modern capitalist state ... moved from a marginal view to one that is hegemonic in global politics" (Abu-Laban and Bakan 2008:644). Prior to this period, many Jewish peoples understood the Zionist idea of creating a Jewish-only state to be accepting of the racist notion that Jews were unable to live with non-Jews and could only live with each other (Davis 1987:2)

Moving toward the establishment of Israel, key figures in the Zionist movement utilized the discourse of European race-thinking which had previously considered Jewish peoples as other to reconfigure Palestinians as the Oriental other in relation to the white Zionist "native." Joseph Weitz (1890-1973), one of the premier architects of the Zionist settlement and then Deputy Chairman of the Board of Directors of the Jewish National Fund (JNF) exemplifies the exclusionary language of "us" and 
"them" used to delineate historic Palestine as Eretz Israel in his now infamous diary entry:

Among ourselves it must be clear that there is no place in the country for both peoples together.... With the Arabs we shall not achieve our aim of being an independent people in this country. The only solution is Eretz Israel ... and there is no other way but to transfer the Arabs from here to the neighbouring countries, transfer all of them, not one village or tribe should remain.... (as quoted in Davis 1987:5; italics added)

The ethno-nationalist goals of Zionism relied upon the racist notion of "'transfer' or ha'avarah - the Hebrew euphemism for ethnic cleansing" (Masalha 2012:28; see also Pappe 2007) to make Palestine a Jewish state. The aim of transference was to rid Palestine of as many Arab Palestinians as possible. The characterization of Arab-Palestinians as a racialized other is rooted in Orientalist ideology which posits the notion of the Eastern non-European other as lesser than the Western/Western European ideal (Said 1978). Orientalization in the Palestinian context is the purposeful racial categorization of the Eastern other to distinguish between a nonwhite citizen other undeserving of rights - the Palestinian - and a white settler citizen deserving of all rights to citizenship — the European/Ashkenazi/white Jewish Israeli. The racial separation between the indigenous Palestinian and the Jewish Israeli is exemplified in Israel's citizenship policies and practices.

\section{Citizenship and Naturalization Forms and Processes}

The category of citizenship and naturalization forms and processes lays bare the dominant myth of Israel as "the only democracy in the Middle East" and grounds the discussion of Israel as a settler colonial state within a framework of racisms that affect not only Palestinians in the Occupied Territories but all citizens of the state. Israel uses law and religion to discursively construct a racialized framework of citizenship and nationality that attempts to legitimize the practice of differential citizenship rights, property and land theft, as well as ethnic cleansing. Through complex legal and religious structural systems and institutionalized practices, Israel's division between Palestinians and Jewish Israelis establishes differential racialized categories based on ethnic and religious groupings (Abu El-Haj 2010:29; Kanaaneh 2002, 2009; Yuval-Davis 1987:39). The most evident examples of Israel's racial rule are found in its distinctions between citizenship and nationality, and the inequitable laws for entrance and land ownership. This is especially apparent in Israel's Law of Return and the Law of Absentee Property.
While the Law of Return enables any Jewish person who immigrates to Israel to be granted automatic citizenship and nationality, under the Law of Absentee Property, Palestinian Arabs who were forced to leave their homes as a result of al Nakba are denied the right to return (Davis 1987:26; see also Abdo 2011:40). Classified as "absentees," they had their homes, lands, and property confiscated (see Fischbach 2011; Leibler 2011). This includes Palestinians who remained within Palestine but were internally displaced — paradoxically labelled "present absentees" (Said 1992:105; Schechla 2001:20). The number of internally displaced Palestinians has increased "since $1948 \ldots$ to at least 238,000 , about a quarter of the Palestinian citizens of Israel, while, among these, the present absentees ... now number some 200,000" (Schechla 2001:22; see also Masalha 2012:6). The expropriation of over 3.2 million dunams of land (approximately 790,700 acres; White 2012:24) resulted in a drastic socioeconomic decline for Palestinians due to the loss of agricultural production compounded by the additional loss of community (Abdo 2011:37). Meanwhile, the over 750,000 Palestinians who were made refugees with the creation of the state in 1948 (Masalha 2003:259) and again following the 1967 occupation of the Palestinian territories - now numbering approximately 5 million not including the internally displaced which would bring the total to about 11 million (Masalha 2012:14; see also Feldman 2012) - continue to be refused entry in violation of the internationally recognized Right of Return (Abu-Laban and Bakan 2008:651; Lentin 2004:par. 2.4).

To carry on its transformation of historical Palestine into a Jewish majority state, Israel has maintained its practices of ethnic cleansing through land expropriation which are not only geopolitically significant and meaningful in a material sense, but are culturally symbolic and intended to alter the story of Palestine. For instance, through the bureaucratic machinery of the Israeli state, 95 percent of state territory is administered via the offices of the Jewish National Fund according to "laws that differentiate between Jew and non-Jew making it illegal for nonJews (read Palestinians) to lease state lands" (Lentin 2004:par. 2.4; see also Davis 1987:26). As a result, most Palestinians who remained within ' $48^{3}$ or what is more commonly considered Israel proper are not legally entitled to own or lease land since Israel has designated almost all of the land within the Green Line as available exclusively to Jews. Known as the "Judaization of land" (Kanaaneh 2009:72; Yiftachel 1997:98), these processes include the erasure of Arab villages through their purposeful

3. '48 is the term used by Palestinians to refer to the geographical space colonized by Israel in 1948; it is also used to refer to the people who remained within historical Palestine but outside of the West Bank and Gaza following the 1967 occupation. 
unrecognition as well as the Hebraicization of Arab villages and street names (Masalha 2012; Suleiman 2004:162-165). In addition to the material dispossession of land and property, displacement of peoples, and the creation of a considerably large refugee population with all of the socioeconomic consequences that result from these processes, the Zionist methods of erasure of Palestinian history, collective memory, and existence are central to the aim of white colonial rule that naturalizes notions of settler nationality and citizenship belonging.

To ensure the whiteness of the state and quell the potential for Palestinian nationalist sentiment and struggle, Israel has further ruptured and fragmented the Palestinian population within ' 48 through the construction of racialized citizenship and civil rights categories based on ethnoreligious divisions. The hierarchical positioning of Palestinian Arabs into separate groupings as Druze, Bedouin, Christian, and Muslim facilitates the promulgation of what Rhoda Ann Kanaaneh (2009:10) refers to as a "good" versus "bad" Arab stereotype. The divisive nature of this classical colonial/imperialist method of divide and conquer (Arar 2012:121 Kanaaneh 2009:3, 10; Sa'di 2011:6) also exemplifies Aihwa Ong's (1996) notion of cultural citizenship wherein discriminatory and separating institutional practices create categories of "desirables" and "undesirables" with particular rights and privileges based on racial and cultural capital. Understanding that "the white-black polarities" (Ong 1996:738) of European imperialism continue to shape relations between peoples in colonial states, Ong's theoretical intervention on citizenship and race posits that societal and state differentiations within racialized groups is based on an ideological "closeness to or distance from white ideal standards" tied to class, religion, ethnicity, and gender (Ong 1996:751). In the case of Israel, the Druze, Bedouin, and Christian are understood as ideologically closer to the ideal white Jewish Israeli than the Muslim.

In contrast to other ethno-religious Palestinian groups, Druze males - as "good Arabs" or in Ong's sense "whiter Arabs" - are conscripted into the Israeli military due to their historical relationship with Zionist forces. Prior to and during al Nakba, the Druze built alliances with "nonArab and non-Sunni-Muslim communities against Arab nationalism" (Kanaaneh 2009:10; Sa'di 2011:7). Bedouins, who also have a history of collaboration with Zionists during 1948, albeit on a much smaller scale, are not required but may voluntarily enter the Israeli security apparatus. Some "friendly [Bedouin] tribes" (Kanaaneh 2009:12; Sa'di 2011:20) are actively encouraged by Israel to enter military service based on common state interests which places them second only to the Druze in the state's ethno-religious hierarchical ranking. Like Bedouins, Christians and Muslims are also not obligated to participate in the military and can enter the security apparatus only through volunteerism; however, based on their ethno-religious position they are viewed with increasing degrees of suspicion on the part of Jewish Israelis (Kanaaneh 2009:62-67; Sa'd 2011). On the Zionist scale of whiteness, Muslims in ' 48 come last and are seen as closest to their racialized counterparts in the Occupied Palestinian Territories.

While primarily performed for economic purposes, Palestinian participation in the military solidifies Israel's racialized distinctions through differential access to citizenship rights and privileges. Yet involvement in the Israeli security apparatus merely increases the possibilities of accessing rights and privileges for Palestinians in ' 48 , it does not guarantee them. Rather than an automatic rights-based citizenship entitlement, the enjoyment of rights for non-Jewish Israeli citizens must be individually negotiated. This negotiated process establishes a system of clientalism and patronage that leads to uncertainty with no guaranteed rights and privileges. For instance, Palestinians living in Israel have unequal access to the "common goods" of running water, electricity, and health care as well as education; access to these goods occurs on the basis of individual resolution and agreement with the Zionist-state bureaucracy rather than through direct citizenship rights (Jabareen 2003; Kanaaneh 2009:74; Kimmerling 2001). This includes financial assistance for higher education which is available for Druze and Bedouins (Kanaaneh 2009:54-56), but remains nebulous under the tiered system of Israeli citizenship. Meanwhile all '48 Palestinians must wait the mandatory three year conscription period for Jewish Israelis and Druze before entering postsecondary institutions where preferential treatment is given to Jewish Israelis who either serve or choose to delay their military service (Kanaaneh 2009:40). Although differences amongst Palestinian minority groups exist in this negotiated process, all hold common the inequality of their citizenship in contrast to Jewish citizens of the state. Despite the marked differentiation that appears on each individual's identification card and the disparities that result from such in accessing state benefits, the contradictory state divide between Palestinians in ' 48 at times collapses group differences together in opposition to the Jewishness of the state.

Forms and processes of differentiation, discrimination, and segregation are structured into the lived experiences of all Palestinians in ' 48 (Arar 2012:118; Kanaaneh 2009:43). Unlike Jewish citizens, '48 Palestinians are not nationals of Israel (Abdo 2011:39) and the practice of social segregation between Jews and non-Jews is noticeably apparent. Due to differential citizenship rights and privileges, most Palestinians and Jewish Israelis live in separate communities where children attend segregated state and nonstate school systems based on nationality and 
religious commitment (Arar 2012:118-119). Vocational options for Palestinians are also limited by racialized citizenship categorization which affects personal income; as a result, poverty levels within Palestinian communities are extremely high (Arar 2012:118). As noted above, even those who willingly enter the state security apparatus are not afforded the same rights as Jewish Israelis, especially in relation to land ownership and land appropriation (Yiftachel 1997). Explicitly, no Palestinians - including Druze - are immune from land confiscation and expropriation, as well as house demolitions, even if they have served in the security apparatus (Kanaaneh 2009:70-78; Sa'di 2011:16-17). While the racial scale of whiteness in Israeli rule constructs Druze as good/ desirable/whitened and Sunni-Muslims as bad/undesirable/darkened, the ethno-nationalist aims of the state ensure the ideological as well as physical separation of the Jewish Israeli.

The racialization of citizenship in Israel is further complicated in relation to Jewish Israelis of European, African, and Arab ancestry. Overlooked in much of the literature, Israeli policy has not only created categories of differently racialized Palestinian citizens, but has also unofficially designated separate tiers of Jewish Israelis to differentiate if not in law then in practice between Ashkenazi (European) Jews, Beta Israel (Ethiopian) or Falasha (literally "immigrant" in Hebrew) Jews, and their Mizrahi (Arab) Jewish counterparts (Abdo 2011; Chehata 2012 Kanaaneh 2009; see also Yuval-Davis 1987:42-44). Racism toward Ethiopian (Chehata 2012) and Arab Jews (Abdo 2011) is prevalent, and includes discrimination against linguistic and cultural practices (Suleiman 2004:153-154). While the tiered system of Israeli citizenship privileges all Jewish peoples, this is especially the case for Ashkenazi Jews (Kanaaneh 2009:54; see also Abdo 2011:34-35; Kanaaneh 2002:157-158). The whiteness of the Zionist project is underscored by the prevalence of discriminatory racialized citizenship practices within Jewish-Israeli society. To advance its colonial aims, Israel utilizes class and gender divides in concert with racialized ethno-religious citizenship processes and forms to create structural disparities within Palestinian society.

\section{Construction and Consolidation of Existing Social Inequalities}

As colonization processes rely on the construction and consolidation of existing social inequalities to further divide the population (Mohanty 1991), it is essential to consider how differentiations in class and gender intersect with racialized ethno-religious distinctions and how these may be manipulated over time to achieve settler colonial state goals. The identification of this divisive strategy which creates or reinforces unequal power relations is also vital to understanding how Palestinians have sought to resist this colonial process. Since the goal of Zionism from the start has been to create an all Jewish state, the establishment of Israel did not initially operate in tandem with preexisting Palestinian class, gender, and religious hierarchical divisions but focused instead on eliminating the indigenous Palestinian population as a whole (Hila 2003:163). While the displacement of close to 800,000 Palestinians during the creation of Israel (Nadeau and Sears 2010:9; Sa'di 2008:382) partially fulfilled the aim of the Zionist state, the shared experiences of displacement, dispossession, and exile established a common history expressed through a Palestinian national identity linked to al Nakba (Hilal 2003). To suppress possible national aspirations amongst the Palestinian population and minimize Israeli ethno-nationalist anxieties over Palestinian liberation efforts, Israel not only created distinct ethno-religious groups within ' 48 but also formed and strengthened class, gender, and ethnic-religious divides within the Palestinian territories.

Class mobility, as Gayatri Spivak reminds us, is critical to understanding the subaltern struggle (see Puar 2007:7) because class privilege enables some circumvention from the genocidal devastation that arises from colonial exploits. As a result of the Oslo process, the solidification of a Palestinian elite entrenched class divisions within the territories and enabled those of a wealthier class to benefit from their own relationships with the colonizers to the detriment of poorer Palestinians, disproportionately affecting women and children (see Hilal 2003; Lagerquist 2003; Roy 1998). Through political patronage and the establishment of monopolies, Oslo strengthened the Palestinian Authority's control within the Occupied Territories for the financial benefit of only a small elite (Roy 1998:25). Dividing the population further, the process also encouraged stronger surveillance of Palestinian liberation and resistance groups through combined Palestinian policing and Israeli efforts (Lagerquist 2003:8). At the same time, Israel remained in control of the borders, internal movement within the territories, most of the land and water, and international trade (Hilal 2003:168-169; Johnson and Kuttab 2001:22-23; Lagerquist 2003:8; Roy 1998:20). To limit Palestinian national struggle efforts, religious conflict was also actively encouraged by the Israeli state (Sa'ar 2006:402). This continues to be the case both in ' 48 and the rest of Palestine with the factional conflict between Fatah and Hamas backed by the Israeli state.

In a related way, Israel has strengthened "clanship loyalties" through preferential ethnic treatment within Palestinian communities in ' 48 as a preventative measure "against political radicalization" and "political mobilization" of Palestinians (Sa'ar 2006:402). A consequence of this 
has been the exacerbation of existing gender inequalities, including the social control of women by boys and men, and in the case of girls and younger women also by older women, justified by moralistic and cultural codes as well as political, economic, and religious arrangements (Herzog and Yahia-Younis 2007:586; see also Abdo 2011:29-30). Despite the limits of this patriarchal rule, women continue to be involved in national liberation and resistance struggles. Moving beyond attempts to divide Palestinians through factionalism, women's participation in political struggle crosses class and religious lines; indeed as Abdo (2008:178) notes, many of the women who are imprisoned for political activities are from well-educated and fairly well-off secular families.

The ability to traverse class divides does not appear to be the case for men, however. Julia Peteet's (1994) research shows that class privilege is an important category of difference in determining a male's experience with violence in relation to political involvement. Although all men, and indeed, all Palestinians including women and children are subject to periods of administrative detention (Falah 2008), Peteet (1994:43) details how men from camps and villages are more likely to experience "bodily inscriptions of violence political mobilization" that are "class bound" than "the politically active urban elite, often from notable families, who have traditionally striven for leadership." Israel's differential treatment of men involved in political activism and resistance based on socioeconomic standing reinforces class divides. Like gender and religious divides, this tactic interrupts and displaces possibilities for collective Palestinian struggle. While Israel constructs or intensifies fissures within Palestinian society to control the population, the state's rule over the sexual body is central to the genocidal violence of the colonial project.

\section{Gender, Sexuality, and Sexual Violence}

To demonstrate the relationship between sexual governance, demography, and genocide, the categories of gender, sexuality, and sexual violence link sexuality, death, and colonial rule to enhance Mohanty's (1991) discussion of relations of ruling over the female sexual body. In its regulation and control of bodies that are deemed to matter or marked as threats, the colonial state merges the Foucauldian notion of biopolitics or the management of life, with necropolitics (thanatopolitics) or the management of death (Ghanim 2008; Mbembé 2003). The objective of the biopolitical is to control life and death at an aggregate level of the population and therefore to control mortality as death is the end limit to power (Foucault 2003:248). The state's regularization and control of death seeks to eliminate the degenerative and the differently abled not only to rid the population of these "inferior races" but to create a stronger, "purer race" (Foucault 2003:255). In contrast to the Foucauldian notion of the biopolitical as a strictly optimizing state strategy of regulation, the necropolitical places the state's right over death at the fore of the political.

Jewish Israeli anxiety related to racialized demographics in Israel underlies a necropolitical aim. Himani Bannerji's (2003) understanding of ethno-demography reverses the order of the Foucauldian notion of demographics linked to optimization. Bannerji (2003) argues that the concern with cultural and numerical ethnicity used to manage and control "majority" and "minority" populations in ethno-nationalist states is "inherently and intrinsically genocidal/ethnocidal" (Bannerji 2003:97) and necessarily connected to women. Rather than ending with the genocidal objectives of the state, her analysis begins with the state's control of the female sexual body in the reproduction and elimination of the other. The regulation of miscegenation, sexuality, and sexual violence which is rife in colonial contexts (Mohanty 1991:17) is evident in Israel's policies and practices.

Although sexual relations between Jewish Israelis and Palestinians are regulated through the prohibition of intermarriage (see Abdo 2011:41; Kanaaneh 2002:44; Lentin 2004; Yuval-Davis 1993), a more central concern for Israel's colonial project rests with the question of ethno-nationalist demographics. To attain a Jewish majority, legal mechanisms ${ }^{4}$ are used to keep apart Palestinians from either side of the Green Line while family planning tactics limit the reproduction of Palestinians within ' 48 (Lentin 2004; see also Schocken 2008). In what Kanaaneh describes as "political arithmetic" (2002:73), the state of Israel prescribes what are considered private choices of families and bodies. While the state actively promotes the birth of Jewish Israelis (Yuval-Davis 1996), Israel's advocacy and sponsorship of family planning clinics and advertisements aim at curtailing Palestinian births. Fusing issues of gender and class, discourses concerning Palestinian women's reproductive rights and reduced family size link having children to material wealth and education (Kanaaneh 2002:74-79). The administration and servicing of family planning by liberal Zionists juxtaposes humanitarian concerns with the state's aim to be an ethnically Jewish majority, and creates ambiguity for Palestinians (Kanaaneh 2002:77). Given that the purpose of Israel's ethnocidal project is to limit, remove, and eliminate the Palestinian population, the regulation of the biopolitical through family planning cannot be viewed as benevolent or benign.

4. See Citizenship and Entry Act of 2003 http://www.knesset.gov.il/laws/special/eng/ citizenship law.htm (Access date: June 29, 2012). 
Israel further masks its ongoing genocidal policies and practices through its discursive construction and marketing as a safe haven for homosexuality. Concealing the connection between the state's ongoing colonization and occupation of Palestine and its own societal violence towards all queers through its "pink washing" efforts, Israel presents itself as a queer friendly, diverse, and democratic state where the rights of all GLBTQ are upheld (Abdulhadi et al. 2011:91). At the same time, Palestinians in the West Bank and Gaza are made into Islamic fundamentalists who are backward, uncivilized, and homophobic (Puar 2011:138; see also Amireh 2010). The portrayal of Israel as modern versus Palestine as primitive blurs the ties between different forms of oppression that "might sustain or even create the conditions and possibility for the other" (Puar 2007:17). While it is crucial not to equate the differences between colonial and sexual oppressions, it is equally important to show the links between these complicated processes and how the discourse of gay rights can be used to further forms of violence toward all Palestinian bodies. Being Palestinian, whether queer or not, is always viewed as a security and demographic threat.

The fixation with ethno-nationalist threat in the Zionist imaginary leads to the further brutalization and exploitation of Palestinian bodies through sexual violence (Abdo 2008:180). The complicated feelings of shame, trauma, and humiliation connected with sexual violence have limited the detailing of this data (Masalha 2012:82; Pappe 2007:211). Indeed, as Ghazi-Walid Falah (2008) reveals in his personal account of imprisonment in Israel, sexual humiliation and assault of male prisoners is little recorded. Yet despite the limitations on the collection of this information, recent scholarly work has made steps toward documenting the state's employment and complicity in sexual violence from the massacre of Deir Yassin on April 9, 1948 to the gang rape and eventual murder of a twelve year old girl in the Negev on August 12, 1949 as well as the use of sexual humiliation and torture against political prisoners (see Masalha 2012:82-83; Pappe 2007; for sexual violence in prisons see Abdo 2008:180; Falah 2008). Changes in social attitudes towards women who are survivors of rape and other sexualized forms of violence further challenge the fear tactics of Israeli rule that attempt to silence Palestinian women's involvement in resistance (Peteet 1994; Sharoni 1995). While problematic gendered views of Palestinian women's bodies continue through the construct of the feminized woman as symbolic of the Palestinian nation which needs to be defended (Amireh 2003:750 751; Massad 1995:471; Sharoni 1995:39), the oppression of Palestinian women - largely understood in the West as connected with traditional culture - must be situated within the context of Israel's colonial re- lations of ruling. The attempt to portray the situation of Palestine as a national struggle rather than one of colonial dispossession relies on gendered notions of nation and state as well as constructions of racialized difference that intersect with gender.

\section{Racialized and Gendered Political Prisoners}

The category of racialized and gendered political prisoners assists in identifying the forms and processes of colonial rule that Israel attempts to obscure in its representation of Palestinian political struggle which is often uncritically perpetuated in Western discourse. The recognition and acknowledgment of Palestinian women's agency in political anticolonial resistance has been continually misconstrued by the West, including by white Western feminists. Represented as powerless victims, feminists in the West have portrayed Palestinian women's participation in armed struggle as a way to gain control over their bodies rather than as a choice to engage in active resistance against colonization (see Abdo's 2008:174 discussion of Dworkin and Victor). In the process of doing so, white feminists have further racialized Palestinian women's role in struggle. Meanwhile, dominant Western discourse has constructed Palestinian men as violent (Goldberg 2008:31) as they are simultaneously emasculated by Israel's disciplinary action in the form of public and private humiliation through beatings, torture, and imprisonment (Peteet 1994:34; Puar 2007:xxiii). Prevented from attaining the military capacity to defeat Israel's well-financed military with extensive high-technology weaponry, Israel reinscribes the notion of the need for force against "Palestinian terror" when the "security" of its Jewish citizens is imperiled (Ghanim 2008:74). But while the feminization of humiliation is said to characterize the Palestinian experience of loss, the subjugated knowledges of Palestinians do not necessarily reflect this view (Lentin 2008:13).

The experiences of women political prisoners not only expose the horrific physical and psychological mechanisms and techniques of abuse and sexual torture, but further bring to light the agency of these women as political prisoners. Akin to the work of Engin Isin and Kim Rygiel (2007) as well as that of Judith Butler (Butler and Spivak 2007), Nahla Abdo's (2008) study on women political prisoners counters Agamben's (1998) claim of "bare life" to illustrate the material and experiential ways in which women contest their abjection. The stories of women fighters - many of whom identify as secular with Marxist-Leninist political associations - locate the motivation for their resistance first in al Nakba and its immediate aftermath of "exile and trauma" (Abdo 2008; Peteet 1994). The enduring involvement of women in struggles against the on- 
going colonization of Palestine and their significant and numerous ways of resisting spaces of enclosure helps to counter the Orientalized and racialized perception of women's role in struggle.

While Israel "continuously refers and appeals to exception, emergency, and a fictionalized notion of the enemy" (Mbembé 2003:14; also Ghanim 2008:72-73; Goldberg 2008:36-37), the sheer number of political Palestinian prisoners - including women and children - that mark the contemporary space of the state attest to the fact that Israeli politics of imprisonment and detainment are not extraordinary events, but rather are central to the structuring network of Israeli settler colonialism. Israel's practices of disciplinary and regulatory control over racialized political bodies occur not only through physical and psychological torture inside the prison, but outside as well through the use of collective punishment methods. Home demolitions, widely documented by human rights organizations, are regularly used by Israel as a method of collective punishment against all Palestinian political prisoners (Abdo 2008:181; Goldberg 2008:39). Meanwhile, the ongoing hunger strikes by female and male prisoners alike - many of whom have been held under administrative detention without formal charge (Abu-Sarah 2012) - illustrates the length that Palestinians are willing to go to demonstrate their refusal to comply with the injustices of Israeli policies and practices. The manner in which Palestinian resistance is presented underlines the significance of discourse to the practice of rule.

\section{“UnMarked" Versus “Marked” Discourses}

The category of "unmarked" versus "marked" discourses helps to reveal how discursive practices are vital to the mechanisms and techniques employed in relations of ruling. While the "unmarked" discourses of citizenship and individual rights are used to create exclusionary and differential rights categories in liberal capitalist states, the "marked" discourses of overt exclusion and racialized and gendered otherness are illustrative of colonial projects (Mohanty 1991:21). The bureaucratic or unmarked discourse of Western rationality which Arendt recognized in the link between national-socialism and imperialism obscures "civilized" practices of state murder (Mbembé 2003:23). Israel actively employs the two discursive techniques to continue their ethno-nationalist pursuits.

In a state that purports to be both Jewish and democratic, the language of tolerance is used within the Green Line to mask Israel's necropolitical aim:

Even when this ethno-nationalism is not actively genocidal, even when it

'tolerates' ... [ethnic] 'minorities,' genocidal or eliminationist premises underwrite it. As with all other ethno-nationalist projects, it constructs a hierarchical set of differences between people living within a national/ political territory on grounds of racialized ethnicities, including religion, thus calling for their erasure from and subordination in the main frame of society, culture and history. (Bannerji 2003:99)

The current narrative which discursively marks Palestinians as an alien/stranger population rather than as natives with irrevocable binding rights to the land began with Zionist myths that "Palestinians did not exist" or that Palestine was "a land without a people" (Golda Meir and Israel Zangwill respectively in Said 1992:5, 7). In contemporary times, the pervasiveness of othering discourse which characterizes Palestinians as alien extends to all areas of media and scholarship including feminist discourse (Abdo 2004:23-24; Abdo 2008:174; Al-Hardan 2008:249; Khalidi 1997:18; Pappe 2008:152,160; Puar 2011). While attempts to silence and erase Palestinian experiences and histories limit the production of these situated knowledges, the discursive representation of Palestinians as terrorist others controls the manner in which Israel and Palestine are discussed and the racialized policies and practices that are implemented and to a large extent accepted in Israeli society and the international arena.

The state's use of racialized discourse (Abu-Laban and Bakan 2011; Ghanim 2008; Goldberg 2008) facilitates the execution of Israel's apartheid policies that segregate communities from one another and limit or prevent mobility, including access to food, water, and education. The continued territorial fragmentation of Palestine - primarily evident in the West Bank - continues to see increased settlements with separate road systems and tunnels and bridges for Jewish settlers and Palestinians (Abujidi 2011:315-319; Korn 2008:121; Weizman 2007:179-181); meanwhile Gaza is completely sealed off and the delivery of basic goods is severely limited and oftentimes prevented altogether (Ghanim 2008:77; Korn 2008:117). The movement of Palestinians inside and outside of West Bank enclaves is restricted (Ghanim 2008:66, 76; Korn 2008:123) and in the case of Gaza movement is near impossible (Ghanim 2008:77; Korn 2008:117). The apartheid wall cuts deeply into West Bank territory to engulf the expanding illegal settlements, and absorb resources such as water and fertile agricultural land (see Weizman 2007:161-179). The consequence of discursively representing Palestinians as racialized others is thus evident in the Occupied Territories.

Apartheid fragmentation is not only present in the discriminatory citizenship policies and practices that permit the walls, roads, checkpoints, and camps that separate Israelis from Palestinians (see Zureik 2011); it is discursively written into the Zionist vision of the state through the 
delineation of Jewish ethno-national identity which supersedes the determination of rights for all racially marked Palestinians. While the Occupied Palestinian Territories serve as the case in point for Achille Mbembé's (2003) necropolitical framework, the techniques of surveillance and occupation as well as territorial fragmentation - although not as excessive - extend beyond the West Bank and Gaza to all of Occupied Palestine or what is considered Israel proper. In the imagined democracy of the ethno-national state, the sovereign disciplines and regulates the body and population through discourses, practices, and processes paradoxical to the liberal notions of equality, rights, and freedoms.

The guise of Israel as a liberal democratic state cannot be reconciled with its racialized origins and its intention to remain a Jewish majority state with special rights and privileges afforded to its Jewish Israeli citizens and exceptional laws that not only prevent Palestinians from enjoying the same but create the conditions for genocidal practices (Bannerji 2003:103; Yiftachel 2006). In recent years, nothing reflects this better than the Loyalty Oath passed on October 10, 2010 which "requires 'nonJewish' citizens to swear allegiance to Israel as 'Jewish and democratic' [and is squarely aimed at] ... Palestinian citizens" (Abdo 2011:49). As Bannerji (2003:97) aptly points out, although the conception of genocide/ethnocide "has been generally spatialized by the western ... political discourse as a third world phenomenon or a phenomenon of 'backward', formerly communist, European states," in considering national imaginaries liberal western states must also be recognized as spaces of genocide/ethnocide. Although Bannerji (2003:98) cautions against the use of exceptional discourse which only reifies constructed differences between states, it is precisely through the view of what is considered exceptional that the normal comes into question, and the divides of tradition or tribal versus modernity, and/or East versus West lead to an interrogation of all sovereign power. It is necessary to underline that all levels of discourse must challenge colonial rule's creation of simplistic categories of differentiation that are used to both divide and assimilate.

\section{Discussion and Conclusion}

The categorical framework outlined here provides a method for a critical antiracist feminist analysis of colonization which understands the complexity of colonial relations of ruling. Through the institutions, policies, and practices of colonial occupation (Mohanty 1991:19-20) and liberal citizenship models (Ong 1996), the construction of racialized discriminatory categories based on class and gender determinations of closeness or distance to whiteness affects how attitudes and discourses are shaped in a global sense. Israel's "discourse of the sacred" (Mbembé 2003:27) which utilizes the historical suffering of Jewish peoples while claiming the divine right to the land of Palestine is often understood by Zionists as exemplary of Foucault's notion of "counter-history" (see Abu El-Haj 2010:31; Goldberg 2008:26). The Zionist goal of an independent state in a land "without a people" invokes the past victimization of Jews in servitude, as exiles, and through brutal genocide, while it disappears the historical presence of the Palestinian people by means of on-going ethnic cleansing and genocide. The reliance on religious as well as secular Zionist narratives reveals a profound contradiction that is obscured through the constant recollection of Jewish pain.

While the discourse of race struggle as a form of counter-history has the potential to be revolutionary, Foucault cautions that the use of counter-history does not belong solely to the oppressed. Racism, according to Foucault (2003:81), is the inverted form of race struggle in which the "theme of racial purity replaces that of race struggle, and when counter-history begins to be converted into biological racism." Since all discourse is dynamic, it can be transformed and used strategically by oppositional groups for a variety of political meanings; historical discourses of race struggle therefore come into conflict in the production of knowledge (Foucault 2003:77). Due to the Holocaust, Zionism has discursively reconfigured race along nationalist rather than explicitly biologically racist lines (Goldberg 2008:30-31; also see Abu El-Haj 2010:32; Lentin 2004; Yuval-Davis 1987). The purposeful division between Palestinian-Arabs and Jews is thus constructed on national difference rather than race (Lentin 2004:par. 2.2).

An antiracist feminist analysis is crucial to understanding and countering the myths of the Zionist construction of Israel. The "relatively recent" (Lentin 2004:par. 2.2) use of the term racism in the Israeli context is critical to producing knowledge of al Nakba and the on-going Palestinian experiences of colonization. The link between discourse and practice is vital to identifying, unsettling, and overcoming injustices of the state. Indeed as Foucault (2003) argues, when power is revealed to be unjust the discourse of race struggle overrides that of the history of sovereignty. In this way the potential for Palestinian counter-history as a truly revolutionary discourse that will overcome that of Zionism is found in the questioning of dissymmetries, disequilibriums, injustice, and the violence that is perpetrated by the Israeli state on the Palestinian people "despite the order of laws, beneath the order of laws, and through and because of the order of laws" (Foucault 2003:79). In striving to decolonize the history of Palestine it is necessary to examine race, class, and gender to complicate simplistic divisions between Palestinians and Israelis in relations of 
ruling; however, to move in the direction of halting the violent policies and practices of the Israeli state against the Palestinian people more must be done to counter the Zionist silencing and erasure of situated Palestinian knowledges that continue to be purposely censored in academia and beyond.

\section{REFERENCES}

Abdo, Nahla. 1996. Orientalism, eurocentrism and the making of theory. Pp 1-29 in N. Abdo, ed., Sociological Thought: Beyond Eurocentric Theory. Toronto: Canadian Scholar's Press.

2004. Writing dislocation, writing the self: Bringing (back) the political into gendered Israeli-Palestinian dialoguing. Pp. 1-33 in N. Abdo and R. Lentin, eds., Women and the Politics of Military Confrontation: Palestinian and Israeli Gendered Narratives of Dislocation. New York: Berghan Books.

2008. Palestinian munadelat: Between western representation and lived reality. Pp. 173-88 in R. Lentin, ed., Thinking Palestine. New York: Zed Books.

2011. Women in Israel: Race, Gender and Citizenship. New York: Zed Books.

Abdulhadi, Rabab, Ayoka Chenzira, Angela Y. Davis, Gina Dent, G. Melissa Garcia, Anna Romina Gueverra, Beverly Guy-Sheftall, Premilla Nadasen, Barbara Ransby, Chandra Talpade Mohanty, and Waziyatawin. 2011. Palestine statement: Justice for Palestine: A call to action from indigenous and women of color feminists. Transforming Anthropology 20(1):90-92.

Abu El-Haj, Nadia. 2010. Racial Palestinianization and the janus-faced nature of the Israeli state. Patterns of Prejudice 44(1):27-41.

Abujidi, Nurhan. 2011. Surveillance and spatial flows in the occupied Palestinian territories. Pp. 313-334 in E. Zureik, D. Lyon, and Y. Abu-Laban, eds. Surveillance and Control in Israel/Palestine: Population, Territory, and Surveillance and Control in Istae
Power. New York: Routledge.

Abu-Laban, Yasmeen and Abigail Bakan. 2008. The racial contract: Israel/Palestine and Canada. Social Identities 14(5):637-660.

2011. The Israelization of social sorting and the Palestinization of the racial contract: Reframing Israel/Palestine and the war on terror. Pp. 276-294 in E. Zureik, D. Lyon, and Y. Abu-Laban, eds., Surveillance and Control in Israel/Palestine: Population, Territory, and Power. New York: Routledge.

Abu-Sarah, Aziz. 2012. Hunger strike highlights forgotten tragedy of Palestinian prisoners. +972 Magazine: Independent Commentary from Israel and the Palestinian territories. [Online]. Accessed 13 June 2012 at http://scar. gmu.edu/icar-news/13784.
Agamben, Giorgio. 1998. Homer Sacer: Sovereign Power and Bare Life, translated by D. Heller-Roazen. Stanford, CA: Stanford University Press.

Al-Hardan, Anaheed. 2008. Understanding the present through the past: Between British and Israeli discourses on Palestine. Pp. 236-53 in R. Lentin, ed., Thinking Palestine. New York: Zed Books

Amireh, Amal. 2003. Between complicity and subversion: Body politics in Palestinian national narrative. The South Atlantic Quarterly 102(4):747-772.

2010. Afterword. GLQ: A Journal of Lesbian and Gay Studies 16(4):635647.

Arendt, Hannah. 1973 [1958]. Origins of Totalitarianism. New York: Harcourt Brace Jovanovich.

Arar, Khalid. 2012. Israeli education policy since 1948 and the state of Arab education in Israel. Italian Journal of Sociology of Education 1:113-145.

Bannerji, Himani. 2003. Demography and democracy: Reflections on violence against women in genocide or ethnic cleansing. Resources for Feminist Research 30(3/4):93-106

Butler, Judith and Gayatri C. Spivak. 2007. Who Sings the Nation-State? Language, Politics, Belonging. New York: Seagull Books.

Chehata, Hanan. 2012. Israel: Promised land for Jews ... as long as they're not black? Race \& Class 53(4):67-77.

Davis, Uri. 1987. Israel: An Apartheid State. London: Zed Books.

Falah, Ghazi-Walid. 1996. The 1948 Israeli-Palestinian war and its aftermath: The transformation and de-signification of Palestine's cultural landscape. Annals of the Association of American Geographers 86(2):256-85.

2008. Geography in ominous intersection with interrogation and torture: Reflections on detention in Israel. Third World Quarterly 29(4):749-766.

Feldman, Ilana. 2012. The challenge of categories: UNRWA and the definition of a 'Palestine Refugee'. Journal of Refugee Studies [Online May 12, 2012]. Access date: July 3, 2012.

Fischbach, Michael R. 2011. British and Zionist data gathering on Palestinian Arab landownership and population during the mandate. Pp. 297-312 in E. Zureik, D. Lyon, and Y. Abu-Laban, eds., Surveillance and Control in Israel/Palestine: Population, Territory, and Power. New York: Routledge.

Foucault, Michel. 2003 [1997]. "Society Must be Defended": Lectures at the Collège de France, 1975-76, edited by M. Bertani and A. Fontana; translated by D. Macey. New York: Picador.

Ghanim, Honaida. 2008. Thanatopolitics: The case of the colonial occupation of Palestine. Pp. 65-81 in R. Lentin, ed., Thinking Palestine. New York: Zed Books.

Goldberg, David T. 2008. Racial Palestinianization. Pp. 25-45 in R. Lentin, ed., Thinking Palestine. New York: Zed Books. 
Gregory, Derek. 2004. The Colonial Present. Blackwell Publishing.

Herzog, Hanna and Taghreed Yahia-Younis. 2007. Men's bargaining with patriarchy: The case of primaries within Hamulas in Palestinian Arab communities in Israel. Gender and Society 21(4):579-602.

Hilal, Jamil. 2003. Problematizing democracy in Palestine. Comparative Studies of South Asia, Africa and the Middle East 23(1\&2):163-172

Isin, Engin and Kim Rygiel. 2007. Abject spaces: Frontiers, zones, camps. Pp. 181-203 in E. Dauphinee and C. Masters, eds., Logics of Biopower and the War on Terror. Hampshire: Palgrave.

Jabareen, Hassan. 2003. The future of Arab citizenship in Israel: Jewish-Zionist time in a place with no Palestinian memory. Pp. 196-220 in D. Levy and Y. Weiss, eds., Challenging Ethnic Citizenship: German and Israeli Perspectives on Immigration. New York: Berghahn Books.

Johnson, Penny and Eileen Kuttab. 2001. Where have all the women (and men) gone? Reflections on gender and the second Palestinian Intifada. Feminist Review 69:21-43.

Kanaaneh, Rhoda Ann. 2002. Birthing the Nation: Strategies of Palestinian Women in Israel. Berkeley: University of California Press.

2009. Surrounded: Palestinian Soldiers in the Israeli Military. Stanford, CA: Stanford University Press.

Khalidi, Rashid. 2001. The Palestinians and 1948. Pp. 12-36 in E.L. Rogan and A. Shlaim, eds., The War for Palestine: Rewriting the History of 1948. New York: Cambridge University Press.

Khalidi, Walid. 1997. Revisiting the UNGA partition resolution. Journal of Palestine Studies 27(1):5-21.

Kimmerling, Baruch. 2001. The Invention and Decline of Israeliness: State, Society and the Military. Berkeley: University of California Press.

Korn, Alina. 2008. The ghettoization of the Palestinians. Pp. 116-30 in R. Lentin, ed., Thinking Palestine. New York: Zed Books.

Lagerquist, Peter. 2003. Privatizing the occupation: The political economy of an Oslo development project. Journal of Palestine Studies 32(2):5-20.

Leibler, Anat E. 2011. "You must know your stock": Census as surveillance practice in 1948 and 1967. Pp. 239-256 in E. Zureik, D. Lyon, and Y. Abu-Laban, eds., Surveillance and Control in Israel/Palestine: Population, Territory, and Power. New York: Routledge.

Lentin, Ronit. 2004. No woman's law will rot this state: The Israeli racial state and feminist resistance. Sociological Research Online 9(3). Accessed 8 June 2012 at http://www.socresonline.org.uk/9/3/lentin.html.

2008. Introduction. Pp. 1-22 in R. Lentin, ed., Thinking Palestine. New York: Zed Books.

Masalha, Nur. 2003. The Politics of Denial: Israel and the Palestinian Refugee Problem. London: Pluto Press.
2012. The Palestine Nakba: Decolonising History, Narrating the Subaltern, Reclaiming Memory. New York: Zed Books.

Massad, Joseph. 1995. Conceiving the masculine: Gender and Palestinian nationalism. Middle East Journal 49(3):467-483.

Mbembé, Achille. 2003. Necropolitics, translated by L. Meintjes. Public Culture 15(1):11-40.

Mohanty, Chandra. T. 1991. Introduction, Cartographies of struggle: Third world women and the politics of feminism. Pp. 1-49 in C.T. Mohanty, A. Russo, and L. Torres, eds., Third World Women and the Politics of Feminism. so, and L. Torres, eds., Third World Womer
Indianapolis: Indiana University Press.

Nadeau, Mary-Jo and Alan Sears. 2010. The Palestine test: Countering the silencing campaign. Studies in Political Economy 85 Spring:7-33.

Ong, Aihwa. 1996. Cultural citizenship as subject-making: Immigrants negotiate racial and cultural boundaries in the United Sates [and comments and reply]. Current Anthropology 37(5):737-62.

Pappe, Ilan. 2007. The Ethnic Cleansing of Palestine. Oxford: Oneworld Publications.

2008. The Mukhabarat state of Israel: A state of oppression is not a state of exception. Pp. 148-69 in R. Lentin, ed., Thinking Palestine. New York: Zed Books.

Peteet, Julie. 1994. Male gender and rituals of resistance in the Palestinian "Intifada": A cultural politics of violence. American Ethnologist 21(1):31-49.

Puar, Jasbir K. 2007. Terrorist Assemblages: Homonationalism in Queer Times. London: Duke University Press

2011. Citation and censorship: The politics of talking about the sexual politics of Israel. Feminist Legal Studies 19:133-142.

Roy, Sara. 1998. The Palestinian economy after Oslo. Current History January: $19-25$.

Sa'ar, Amalia. 2006. Feminine strength: Reflections on power and gender in Israeli-Palestinian culture. Anthropological Quarterly 79(3):397-430.

Sa'di, Ahmad H. 2008. Remembering al Nakba in a time of amnesia. Interventions: International Journal in Postcolonial Studies 10(3):381-399.

2011. The role of social sorting and categorization under exceptionalism in controlling a national minority: The Palestinians in Israel. The New Transparency: Surveillance and Social Sorting. Working Paper V: 1-43. Ben Gurion Univeristy of the Negev, Department of Politics and Government.

Said, Edward W. 1978. Orientalism. London: Penguin. 1992 [1979]. The Question of Palestine. New York: Vintage.

Schechla, Joseph. 2001. The invisible people come to light: Israel's "internally displaced" and the "unrecognized villages." Journal of Palestine Studies 31(1):20-31. 
Schocken, Amos. 2008. Citizenship law makes Israel an apartheid state. In Ha'aretz [Online]. Accessed 27 June 2012 at http://www.haaretz. com/print-edition/opinion/citizenship-law-makes-israel-an-apartheidstate1.248635. June 27.

Sharoni, Simona. 1995. Gender and the Israeli-Palestinian Conflict: The Politics of Women's Resistance. Syracuse, NY: Syracuse University Press.

Sheehi, Stephen. 2010. Teaching in a state of fear: Middle East studies in the teeth of power. Pp. 262-279 in A.J. Nocella, S. Best, and P. McLaren, eds., Academic Repression: Reflections for the Academic Industrial Complex. Oakland, CA: AK Press.

Suleiman, Yasir. 2004. When languages collide: Language and conflict in Palestine and Israel. Pp. 137-217 in A War of Words: Language and Conflict in the Middle East. Edinburgh: Cambridge.

Weizman, Eyal. 2007. Hollow Land: Israel's Architecture of Occupation. New York: Verso.

White, Ben. 2012. Palestinians in Israel: Segregation, Discrimination and Democracy. London: Pluto Press.

Wolfe, Patrick. 2006. Settler colonialism and the elimination of the native. Journal of Genocide Research 8(4):387-409.

Yiftachel, Oren. 1997. The political geography of ethnic protest: Nationalism, deprivation and regionalism among Arabs in Israel. Transactions of the Institute of British Geographers New Series 22(1):91-110. 2006. Ethnocracy: Land and Identity Politics in Israel/Palestine. Philadelphia: University of Pennsylvania Press.

Yuval-Davis, Nira. 1987. Women/nation/state: The demographic race and national reproduction in Israel. Radical America [Online] 21(6):37-60. 1993. Gender and nation. Ethnic and Racial Studies 16(4):621-632. 1996. Woman and the biological reproduction of the "Nation." Women's Studies International Forum 19(1/2):17-24.

Zureik, Elia. 2011. Colonialism, surveillance, and population control: Israel/Palestine. Pp. 3-46 in E. Zureik, D. Lyon, and Y. Abu-Laban, eds., Surveillance and Control in Israel/Palestine: Population, Territory, and Power. New York: Routledge.

Madalena Santos is a PhD Candidate in Sociology at Carleton University. Her research interests are in the areas of settler colonialism, anti-racist feminism, and creative forms of political resistance with a particular focus on Palestine. Her studies use a critical interdisciplinary approach to examine how discourses and practices are used to legitimize as well as counter social injustice and human rights abuses. 